\title{
ÓSMY ROZDZIAł ADHORTACJI AMORIS LAETITIA W INTERPRETACJI KARDYNAŁA F. COCCOPALMERIO
}

DOI: http://dx.doi.org/10.12775/TiCz.2019.032

Streszczenie. Szczególną trudność w recepcji adhortacji Amoris laetitia sprawia jej ósmy rozdział, dotyczący towarzyszenia, rozeznawania oraz włączania osób, znajdujących się w nieregularnej sytuacji małżeńskiej. Artykuł przedstawia niewątpliwie najważniejszy głos w tej sprawie, czyli główne myśli „Przewodnika po ósmym rozdziale adhortacji Amoris laetitia papieża Franciszka”, autorstwa kardynała Francesco Coccopalmerio, przewodniczącego Papieskiej Rady Tekstów Prawnych (w latach 2007-2018). Autor artykułu ukazuje zamysł oraz główne wątki dokumentu - przewodnika, bazującego oraz wyjaśniającego trudne wątki papieskiej adhortacji. Najpierw podkreśla szacunek dla obowiązującej doktryny, przy jednoczesnej konieczności duszpasterstwa osób w sytuacjach nieregularnych. Następnie ukazuje uwarunkowania, w jakich znajdują się osoby, po czym naświetla relacje doktryny i normy do osoby w duszpasterstwie.

Słowa kluczowe: adhortacja Amoris laetitia; kard. F. Coccopalmerio; rozwiedzeni w nowych związkach; rozeznawanie z osobami rozwiedzionymi; dostęp do sakramentów.

Abstract. Understanding the Message of the Eighth Chapter of the Exhortation Amoris Laetitia with the Guidance of Cardinal F. Coccopalmerio. A special dif-

* Doktorant w Katedrze Duszpasterstwa Rodzin na Katolickim Uniwersytecie Lubelskim Jana Pawła II. 
ficulty in the reception of the Exhortation Amoris Laetitia is its eighth chapter, concerning the accompanying, discerning with and inclusion of persons who are in an irregular marital situation. The article presents undoubtedly the most important voice in this matter, namely the main thoughts from the guide, "The Eighth Chapter of the Apostolic Post-Synodal Exhortation Amoris Laetitia" written by Cardinal Francesco Coccopalmerio, chairman of the Pontifical Council for Legislative Texts (during the years 2007-2018). The author of the article portrays the idea and main themes of this document - a guidebook, building on and explaining the difficult topics of the papal exhortation. First, he emphasizes respect for the currently in force doctrine, and at the same time the necessity of pastoral care of people in irregular situations. Next, he illustrates the conditions in which these persons find themselves, and then illuminates the relations of doctrine and norms to the person in pastoral care.

Key words: exhortation Amoris Laetitia; Cardinal F. Coccopalmerio; divorced persons in new relationships; discernment with divorced people; access to the sacraments.

Niewątpliwie rzadko który papieski dokument wywołuje tak ożywioną dyskusję w Kościele i poza nim jak adhortacja Amoris laetitia. Zainicjowała ją treść adhortacji, a także zawarte w niej wskazanie wypracowania przez biskupów wytycznych dla kościołów lokalnych oraz pojawiające się dokumenty episkopatów. Ożywione dyskusje teologów nad interpretacją dokumentu miewają charakter konstruktywnego dialogu, ale też nie brakuje w nich napięć, konfliktów i przeciwstawnych stanowisk, zwłaszcza wśród teologów moralistów. Na gruncie rodzimej teologii odbywają się konferencje i dyskusje naukowe, powstają publikacje prezentujące pogłębioną refleksję nad całością adhortacji oraz rozdziałem ósmym ${ }^{1}$. W kontekście szerszym cennym głosem w dyskusji jest książka

${ }^{1}$ Zob. J. Goleń (red.), Towarzyszyć małżeństwu i rodzinie. Inspiracje adhortacji apostolskiej Amoris laetitia dla duszpasterstwa rodzin, Lublin 2017; J. Goleń, R. Kamiński, G. Pyźlak, Catholic Family Ministry. The Scientific Reflection and Practical Ministry of the Church, Lublin 2018; W. Góralski, Adhortacja apostolska Amoris laetitia papieża Franciszka. Prezentacja dokumentu z komentarzem do nn. 300-308, Płock 2016; I. Mroczkowski, Etos miłosierdzia a wierność małżeńska. Moralne dylematy osób żyjących w związkach niesakramentalnych, Płock 2017; K. Glombik, Wokół interpretacji „Amoris laetitia”. Próba wyttumaczenia niektórych wątpliwości, „Etos” 30 (2017) nr 4 (120), s. 301-317; J. Kupczak, Źródła sporu o Amoris laetitia, Poznań 2018. 
włoskiego filozofa R. Buttiglionego ${ }^{2}$, poprzedzona wstępem kardynała G. L. Müllera, będąca rzeczową i spokojną odpowiedzią na krytykę narosłą wokół adhortacji. Jednak bez wątpienia za głos najwyższej rangi trzeba uznać oficjalną wypowiedź ówczesnego przewodniczącego Papieskiej Rady Tekstów Prawnych kardynała Francesco Coccopalmerio, opublikowaną także w języku polskim³

Już pobieżna lektura przewodnika ujawnia, że kardynał Coccopalmerio nie zadowala się prostymi wyjaśnieniami, ale osadza nauczanie Franciszka w szerszym kontekście historycznym i w hermeneutyce proponowanej przez papieża. Autor, wychodząc od wykładni Kościoła dotyczącej małżeństwa i rodziny, wskazuje na konieczność duszpasterstwa w sytuacjach nieregularnych, ukazuje uwarunkowania, w jakich znajdują się osoby, a następnie analizuje relację między doktryną i normą a osobą, która podejmuje decyzje i działa w konkretnej sytuacji. Wnioski wynikające z powyższych refleksji pozwalają kardynałowi w dalszych rozdziałach zmierzyć się z tematem integracji osób żyjących w nieregularnej sytuacji. Ostatecznie ukazuje on, czym jest „hermeneutyka osoby”, będąca istotnym elementem optyki duszpasterskiego posługiwania papieża Franciszka.

\section{RESPEKTOWANIE OBOWIAZZUJĄCEJ DOKTRYNY I KONIECZNOŚĆ DUSZPASTERSTWA OSÓB W SYTUACJACH NIEREGULARNYCH}

Punktem wyjścia w drodze ku pełniejszemu zrozumieniu papieskiej adhortacji jest dla kardynała Coccopalmerio wykładnia doktryny o małżeństwie i rodzinie. Nauka ta jest jednoznacznie zawarta w adhortacji Amoris laetitia i przedstawia małżeństwo jako sakramentalne, jedno, nierozerwalne i do śmierci ${ }^{4}$. Głos Kardynała z Watykanu wydaje się kluczowym w kontekście wysuwanych wątpliwości i nadętych zarzutów, że papież dokonał „przewrotu kopernikańskiego” w nauce o sakramental-

2 Zob. R. Buttiglione, Przyjacielska odpowiedź krytykom Amoris Laetitia, Kraków 2018.

3 F. Coccopalmerio, Przewodnik po ósmym rozdziale adhortacji Amoris laetitia papieża Franciszka, Kraków 2017.

4 Por. Franciszek, Posynodalna adhortacja apostolska Amoris laetitia, 292, 298, 300, 301, 307 [dalej skrót: AL]. 
ności małżeństwa i sakramencie pokuty, minimalizując wymagania Ewangelii ${ }^{5}$. Tymczasem nauczanie Franciszka dotyczące małżeństwa w niczym nie odbiega od obowiązującego w Kościele od początku, przypomnianego przez Sobór Watykański II, a szczegółowo ujętego przez papieża Jana Pawła II $^{6}$. Franciszek nie wprowadza także żadnych zmian w nauczaniu dotyczącym grzechu cudzołóstwa. Kardynał G. Müller dobitnie podkreśla, że Amoris laetitia nie zmienia dotychczasowej nauki katolickiej. Postulat Franciszka, odnoszący się do duszpasterstwa zorientowanego także na osoby żyjące w związkach niesakramentalnych, nie ma nic wspólnego $\mathrm{z}$ etyką sytuacjonistyczną ani nie stoi w sprzeczności $\mathrm{z}$ nauką zawartą w encyklice Veritatis splendor Jana Pawła $\mathrm{II}^{7}$.

Istotnym rysem nauczania papieża Franciszka jest dążenie, aby z większą niż dotąd wrażliwością i troską duszpasterską, postrzegać człowieka pośród jego uwarunkowań. Sytuacja nieregularna nie musi bowiem z samego faktu oznaczać pozbawienia łaski uświęcającej. Ponadto Papież stwierdza, że nie możemy przemilczeć istnienia takich form związków, które choć są sprzeczne z ideałem, to jednak realizują pewne dobro częściowo lub analogicznie 9 . Dla duszpasterstwa eklezjalnego jest to jednoznaczny sygnał, że Franciszek, pozostając wiernym doktrynie Kościoła o małżeństwie i rodzinie, dostrzega i głośno mówi o problemie sytuacji nieregularnych. Uwypuklając perspektywę osoby i jej czynów, próbuje znaleźć odpowiedź na potrzeby wszystkich członków Kościoła. Stanowisko Piotra naszych czasów nawiązuje do wniosków ojców synodalnych zawarte w Relacji Końcowej synodu z 2015 roku, którzy zauważyli dewaluację rozumienia i akceptacji małżeństwa sakramentalnego, wynikłą z wielu uwarunkowań światopoglądowych, filozoficznych oraz społeczno-

${ }^{5}$ Por. T. P. Terlikowski, Franciszek zrywa $z$ Janem Pawłem, https://tygodnik.tvp. pl/35089570/franciszek-zrywa-z-janem-pawlem [data dostępu: 04.10.2018].

${ }^{6}$ Por. Jan Paweł II, Posynodalna adhortacja apostolska Familiaris consortio, 13 [dalej skrót: FC].

${ }^{7}$ Por. G. L. Müller, Przedmowa. Dlaczego adhortacja Amoris laetitia może i powinna być rozumiana $w$ sensie ortodoksyjnym, w: R. Buttiglione, Przyjacielska odpowiedź krytykom Amoris Laetitia, s. 8.

8 Por. AL 301.

${ }^{9}$ Por. AL 292. 
-gospodarczych ${ }^{10}$. Dlatego za doniosłe wyzwanie duszpasterskie papież uważa zarówno troskę o więzi w małżeństwach sakramentalnych, jak również towarzyszenie duszpasterskie parom egzystujących w sytuacjach nieprawidłowych ${ }^{11}$.

Kardynał Coccopalmerio wyróżnia trzy postawy, jakimi powinni wykazywać się duszpasterze w relacji do osób żyjących w związkach nieformalnych. Po pierwsze, powinni oni poznać motywy osób, które wybrały taką sytuację, a po drugie, należy powstrzymać się od pochopnego potępienia takich związków, aby rozpocząć dialog. Po trzecie, dialog duszpasterski nie oznacza afirmacji sytuacji nieregularnej, ale duszpasterskie poszukiwanie dróg dojścia do pełni świętości w małżeństwie ${ }^{12}$.

\section{UWARUNKOWANIA, W JAKICH ZNAJDUJĄ SIĘ OSOBY}

Przechodząc do istoty sprawy, kardynał Coccopalmerio wyodrębnia trzy sytuacje, w których osoba żyjąca w związku niesakramentalnym może być wolna od grzechu śmiertelnego. Pierwszą jest nieznajomość normy. Druga sytuacja zakłada znajomość normy, ale niezdolność osoby do uznania jej za dobrą. Trzecia dotyczy zewnętrznych uwarunkowań, które „ograniczają zdolność podejmowania decyzji”, zwłaszcza wtedy, gdy zachowanie normy będzie wiązało się z popełnieniem nowej winy ${ }^{13}$.

Jak zaznacza purpurat, dwie pierwsze drogi nie wymagają szerszego tłumaczenia. Jednak wiele pytań rodzi się w związku z trzecią sytuacją. Aby móc uwzględniać uwarunkowania osób, które znajdują się w związ$\mathrm{ku}$ niesakramentalnym, trzeba stwierdzić występowanie określonych warunków: „nowy związek, który umocnił się z czasem; kolejne dzieci; sprawdzona wierność, wielkoduszne poświęcenie, zaangażowanie chrześcijańskie; świadomość nieprawidłowości swoje sytuacji; wielka trudność,

${ }^{10}$ Por. Synod Biskupów. XIV Zgromadzenie Ogólne, Relacja końcowa Synodu Biskupów dla ojca świętego Franciszka, 70-71.

${ }^{11}$ Por. J. Golen, The Challenges of Accompanying Families in Light of the Apostolic Exhortation Amoris Laetitia, „Rocznik Teologii Katolickiej”, t. XVII/1, 2018, s. 112-115.

12 Por. Coccopalmerio, Przewodnik po ósmym rozdziale adhortacji Amoris laetitia, 2.2.

13 Por. tamże, 3.3. 
by wycofać się bez poczucia w sumieniu, że popadłoby się w nowe winy; ważne powody, na przykład wychowanie dzieci; niemożność uczynienia zadość obowiązkowi rozstania się" ${ }^{14}$. Naczelną racją przemawiającą za uwzględnieniem powyższych uwarunkowań jest fakt, że zakończenie związku nieregularnego, wiązałoby się z wyrządzeniem krzywdy innym osobom. Warunkiem sine qua non dla zastosowania tej drogi postępowania w rozeznawaniu sytuacji osób rozwiedzionych żyjących w nowym związku jest ich wyraźna świadomość nieprawidłowości swojej sytuacji, a jednocześnie zamiar albo przynajmniej pragnienie zmiany sytuacji, w której się znalazły ${ }^{15}$.

Nietrudno dostrzec, że papież Franciszek nawiązuje do adhortacji Familiaris consortio, która także wskazywała na potrzebę rozeznawania sytuacji osób:

Pojednanie w sakramencie pokuty - które otworzyłoby drogę do komunii eucharystycznej - może być dostępne jedynie dla tych, którzy żałując, że naruszyli znak Przymierza i wierności Chrystusowi, są szczerze gotowi na taką formę życia, która nie stoi w sprzeczności z nierozerwalnością małżeństwa. Oznacza to konkretnie, że gdy mężczyzna i kobieta, którzy dla ważnych powodów - jak na przykład wychowanie dzieci - nie mogąc uczynić zadość obowiązkowi rozstania się, postanawiają żyć w pełnej wstrzemięźliwości, czyli powstrzymywać się od aktów, które przysługują jedynie małżonkom ${ }^{16}$.

Właśnie w tym miejscu Franciszek, zachowując ciągłość nauczania, idzie o krok dalej niż jego poprzednicy. Podejmuje temat nierozwiązanego napięcia, które powstało w wyniku 84. punktu Familiaris consortio. Choć Jan Paweł II zauważał trudną sytuację małżonków rozwiedzionych i żyjących w nowych związkach, to jednak nie wskazał konsekwentnie dróg działania Kościoła wobec nich. Pomimo że podkreślił, iż niektórzy bez swojej winy zostali porzuceni, bądź też żywią subiektywne przekonanie sumienia o nieważności ich pierwszego małżeństwa, to jednak utrzymał w mocy zakaz komunii dla osób będących w nieregularnych sytuacjach,

\footnotetext{
14 Tamże.

15 Por. tamże.

16 FC 84.
} 
z wyjątkiem par gotowych na życie w pełnej wstrzemięźliwości. Franciszek rozwija istniejące stanowisko poprzednich papieży Jana Pawła II i Benedykta XVI poprzez dopuszczenie wniosków z rozróżniania odmiennych sytuacji osób w obszarze duszpasterstwa ${ }^{17}$.

Obecny Papież niweluje w ten sposób istniejącą do tej pory niespójność i niekonsekwencję w stosowaniu wobec osób rozwiedzionych żyąacych w nowych związkach norm moralnych dotyczących odpowiedzialności osoby za czyn. Konsekwentnie nie zatrzymuje się jedynie na przedmiocie czynu moralnego, ale uwzględnia intencję działającego oraz okoliczności. Podkreśla, mocniej niż dotychczas, potrzebę uwzględniania roli sumienia wiernych oraz zwraca uwagę na uwarunkowania podmiotowe i ograniczenia (czynniki), których nie można pomijać przy ocenie moralnej konkretnego czynu osoby ${ }^{18}$. Wskazuje, że trzeba $\mathrm{z}$ większą wrażliwością pochylić się nad sytuacjami, gdzie małżonkowie niesakramentalni nie potrafią podjąć się życia we wzajemnej relacji z jednoczesnym wyrzeczeniem się współżycia przez obojga partnerów. Papież Franciszek, powołując się na konstytucję Gaudium et spes (KDK 51), stwierdza, że wskutek braku pewnych „wyrazów intymności, nierzadko wierność może być wystawiona na próbę, a dobro potomstwa zagrożone"19. Piotr naszych czasów stosuje soborowy zapis odnoszący się do życia w małżeństwie do par żyjących w związkach niesakramentalnych. Zabieg ten komentuje kardynał Coccoplamerio, stwierdzając, że jeżeli życie ,jak brat z siostrą” jest w mocy niesakramentalnych małżonków, to powinni tak czynić. Jednakże, jeżeli takie życie powoduje poważne trudności i mogłoby prowadzić do rozpadu związku, to para nie będzie do tego zobowiązana, jednocześnie nie popadając w stan utraty łaski uświęcającej ${ }^{20}$. W takich okolicznościach Kościół zaprasza pary niesakramentalne na drogę rozeznania

17 Por. E. Schockenhoff, Zerwanie z tradycją czy niezbędny dalszy rozwój? Dwa sposoby rozumienia posynodalnej adhortacji Amoris laetitia, Zjazd Stowarzyszenia Teologów Moralistów, Nysa (12.06.2017).

18 J. Goleń, Pastoral Accompaniment for People in Irregular Situations, w: Catholic Family Ministry. The Scientific Reflection and the Practical Ministry of the Church, red. J. Goleń, R. Kamiński, G. Pyźlak, Lublin 2018, s. 459 nn.; zob. AL 37, 303, 301-302.

19 AL 298, przypis 329.

${ }^{20}$ Por. tamże, 301; Coccopalmerio, Przewodnik po ósmym rozdziale adhortacji Amoris laetitia, $3.1 ; 3.4$ b). 
odpowiedzialności moralnej, zwłaszcza wtedy, gdy osoba - oprócz wyżej ukazanych warunków - przejawia postawę ewangelicznego nawrócenia, żalu i skruchy oraz pragnie odmienić swoją sytuację, ale jednocześnie nie może tego pragnienia zrealizować w chwili obecnej ${ }^{21}$.

Papież Franciszek nie formułuje nowych zasad postępowania, gdyż zamieniałoby to problem duszpasterski na kazuistyczny. Mobilizuje jednak duszpasterzy do wspólnego z penitentem rozeznawania sytuacji każdej osoby znajdującej się w nieregularnej sytuacji, aby umożliwić jej powrót na drogę zbawienia ${ }^{22}$. Rozeznanie powinno być dłuższym procesem i dokonywać się $\mathrm{w}$ dialogu na forum wewnętrznym. Szczera rozmowa z kapłanem na forum sakramentu pokuty i pojednania, umożliwia zaufanie oraz prawidłową ocenę doświadczanych trudności. W spotkaniu tym może się zostać podjęte postanowienie podjęcia drogi nawrócenia złożonej z kolejnych kroków, które będą rozwijać i prowadzić do coraz pełniejszego uczestnictwa w życiu Kościoła, a w pewnych przypadkach także do otrzymania rozgrzeszenia i przyjęcia Eucharystii ${ }^{23}$. Wymaga to odpowiedzialności ze strony osoby żyjącej w sytuacji nieregularnej oraz roztropności duszpasterza, zdającego sobie sprawę z powagi sprawy, jaka jest podejmowana i poddawana jego ocenie ${ }^{24}$. Wspomniany powyżej proces rozeznawania musi dokonywać się zgodnie z nauczaniem Kościoła, wytycznymi biskupa, a w razie potrzeby z odwołaniem się do decyzji władzy kościelnej ${ }^{25}$.

${ }^{21}$ Por. Coccopalmerio, Przewodnik po ósmym rozdziale adhortacji Amoris laetitia, $3.7 ; 3.8$.

${ }^{22}$ Por. Buttiglione, Przyjacielska odpowiedź krytykom Amoris Laetitia, s. 50.

${ }_{23}$ Por. Coccopalmerio, Przewodnik po ósmym rozdziale adhortacji Amoris laetitia, 3.7; Diocesi di Roma, "La letizia dellamore": il cammino delle famiglie a Roma (19.09.2016), 4. VI.

24 Por. AL 300.

25 AL 300. Kardynał Coccopalmerio wyjaśnia: „Bardzo słuszna okazuje się w tym przypadku znana zasada: Nemo iudex in causa propria (nikt nie jest sędzią we własnej sprawie). Władzą kościelną jest, przynajmniej w normalnych warunkach, proboszcz, który zna bezpośrednio te osoby, i dlatego może wyrazić adekwatny osąd delikatnej sytuacji. Może się jednak okazać, że będzie konieczne, a przynajmniej pomocne, skorzystanie $\mathrm{z}$ rady kurii biskupiej, a wówczas ordynariusz diecezji zaproponuje, tak jak to jest przewidziane $\mathrm{w}$ trudnych przypadkach dotyczących małżeństwa, odpowiednie konsultacje albo udzieli specjalnej władzy dopuszczania w takich przypadkach do sakramentu po- 
W procesie rozeznawania, zwieńczonym wprowadzeniem małżonków niesakramentalnych na drogę nawrócenia, należy zadbać, aby zapobiec zgorszeniu, rozumianemu jako wprowadzenie wiernych w błąd, jakoby Kościół akceptował sytuacje nieregularne na równi z małżeństwem kanonicznym. Papież wyraźnie piętnuje przypadki, w których dana osoba wiedząc, że żyje w grzechu, traktuje ten stan jako część ideału chrześcijańskiego i nie wykazuje zamiaru nawrócenia ${ }^{26}$. A zatem - jak pisze R. Buttiglione - papież Franciszek nie proklamuje etyki sytuacyjnej, w myśl której subiektywny brak winy stanowiłby wystarczający powód, aby dopuścić niesakramentalnych małżonków do sakramentu pokuty i Eucharystii ${ }^{27}$. W kwestii ewentualnego dopuszczenia do sakramentów tych wiernych, którzy spełniają ukazane powyżej warunki, kardynał Coccopalmerio uważa, że „możemy z całą pewnością i spokojem sumienia stwierdzić, że doktryna Kościoła została w tej sprawie zachowana” ${ }^{28}$.

\section{DOKTRYNA I NORMA A OSOBA}

W celu uzasadnienia, kardynał Coccopalmerio podejmuje refleksję nad relacją doktryny i normy w stosunku do konkretnej osoby w jej subiektywnych uwarunkowaniach. Osoba jest równa osobie, ale poprzez swoje wewnętrzne przymioty różni się od pozostałych. Hermeneutyka, jaką proponuje Franciszek, opiera się na założeniu, że osoba jest wartością samą w sobie. Żadne okoliczności, jak strukturalna specyfika czy kondycja moralna, nie są w stanie obniżyć tej wartości. Dlatego wyraźnie sprzeciwia

kuty i eucharystii”. Coccopalmerio, Przewodnik po ósmym rozdziale adhortacji Amoris laetitia, 3.7.

${ }^{26}$ Por. AL 297. Spowiednik podczas rozeznania może dojść do przekonania, że z ważnego powodu nie może udzielić osobie rozgrzeszenia. Wówczas jednak powinien udzielić jej wsparcia i błogosławieństwa, towarzyszyć nadal z cierpliwością i wskazać drogę postępowania. J. Goleń, Pastoral Accompaniment for People in Irregular Situations, w: Catholic Family Ministry. The Scientific Reflection and the Practical Ministry of the Church, red. J. Goleń, R. Kamiński, G. Pyźlak, Lublin 2018, s. 463.

${ }^{27}$ Por. Buttiglione, Przyjacielska odpowiedź krytykom Amoris Laetitia, s. 85.

${ }^{28}$ Coccopalmerio, Przewodnik po ósmym rozdziale adhortacji Amoris laetitia, 3.8. 
się wykluczaniu kogokolwiek ${ }^{29}$. Adhortacja Amoris laetitia właśnie w tej ontologicznej perspektywie ujmuje osobę ludzką i jej czyny. Wskazują na to niejednokrotnie użyte terminy, takie jak: „uwarunkowania”, „okoliczności łagodzące”, „słabość” czy „kruchość”30. Mogłoby wydawać się rzeczą oczywistą, że nauka o okolicznościach łagodzących winę moralną jest cały czas obecna w nauczaniu Kościoła ${ }^{31}$. Mowa tu o okolicznościach i czynnikach ograniczających dobrowolność, a co za tym idzie, odpowiedzialność moralną osoby. W tym kontekście papież Franciszek akcentuje rolę dobrze uformowanego sumienia. Takie sumienie $\mathrm{z}$ jednej strony będzie apelowało i wskazywało człowiekowi, że dana sytuacja nie odpowiada obiektywnym wymogom Ewangelii, z drugiej zaś podpowie, że choć obecny stan rzeczy nie osiąga $\mathrm{w}$ pełni, obiektywnego ideału, to jednak w danej chwili jest wielkoduszną odpowiedzią, jaką dany człowiek może dać Bogu pośród konkretnej złożoności swoich ograniczeń ${ }^{32}$.

Jeżeli pokusić się o spuentowanie adhortacji o rodzinie dwoma pojęciami, to z pewnością byłyby nimi: integracja i hermeneutyka osoby. Pierwsze jest programem duszpasterskim, a drugie jego uzasadnieniem. Franciszek w swoim dokumencie zachęca do dwóch form integracji. Pierwszym jest sprawowanie posługi, a drugim praktykowanie miłości braterskiej. W stosunku do małżeństw niesakramentalnych trzeba więc wykazać się logiką integracji zmierzającą do włączenia w Ciało Chrystusa i otwarcia na przyjęcie radosnego i owocnego doświadczenia relacji z Bogiem ${ }^{33}$. Działania duszpasterskie nigdy nie powinny zmierzać ku wykluczeniu i ekskomunice, ale ku wprowadzeniu człowieka w jedność z Chrystusem, aby stał się żywym członkiem Jego Ciała. Naczelnym prawem chrześcijan zawsze powinna być miłość braterska. Dlatego należy dążyć do takiego sposobu pasterskiego posługiwania, który prowadzi niedoskonałych ludzi do dojrzewania poprzez via caritatis $^{34}$.

29 Por. Franciszek, Adhortacja apostolska Evangelii gaudium, 35, 53-54. 59-60 [dalej skrót: EG]; por. AL 297.

${ }^{30}$ Por. Coccopalmerio, Przewodnik po ósmym rozdziale adhortacji Amoris laetitia, 4.2 .

31 Zob. Katechizm Kościoła Katolickiego, Poznań 1994, 1735, 2352.

32 Por. AL 303.

${ }^{33}$ Por. tamże, 299.

${ }^{34}$ Coccopalmerio, Przewodnik po ósmym rozdziale adhortacji Amoris laetitia, 5.2. 
Logika miłosierdzia zakłada Kościół misyjny zorientowany na włączanie i integrowanie, a nie na wykluczanie i dzielenie ludzi. Dlatego z Amoris laetitia wybrzmiewa jednoznaczny sprzeciw wobec jakiejkolwiek marginalizacji osoby ludzkiej. Kardynał Coccopalmerio ukazuje Franciszka jako pasterza, który w żadnym stopniu nie neguje doktryny Kościoła, lecz przyjmuje grzesznika niczym miłosierny ojciec z przypowieści Łk 15,1-7.11-32 ${ }^{35}$. Choć Papież widzi i docenia rolę rygorystycznego duszpasterstwa, które jest precyzyjne, to jednak zachęca ludzi Kościoła do zwracania uwagi na dobro obecne pośród słabości ${ }^{36}$.

Postulat papieża zawarty w Amoris laetitia nie jest więc prostym domaganiem się możliwości przystępowania do Komunii świętej przez osoby rozwiedzione, żyjące w powtórnych związkach. Jest on zachętą dla wszystkich ludzi Kościoła, aby towarzyszyli w dojrzewaniu do ideału tym, którzy tworzą związki niesakramentalne. Duszpasterstwo rodzin ma proklamować małżeństwo sakramentalne oraz troszczyć się o dojrzewanie miłości i umacnianie małżeńskich więzi ${ }^{37}$, a jednocześnie nawiązywać dialog duszpasterski z tymi, którzy żyją w sytuacjach nieregularnych. Wówczas będzie ono lepiej uwzględniało sytuację egzystencjalną i dynamizowało do otwarcia na ewangelię małżeństwa w całej pełni ${ }^{38}$.

Franciszek mobilizuje Kościół do zauważenia ogromnego potencjału duszpasterskiego w sytuacjach niedoskonałych. Wskazuje, aby wychodząc od sytuacji egzystencjalnej człowieka, pobudzać jego dojrzewanie do przyjęcia ewangelicznych wymogów. Ewangelia rodziny nie jest skierowana tylko do tych, którzy już spełniają wymagania małżeństwa chrześcijańskiego, ale także do będących w drodze do tej rzeczywistości. Zadaniem duszpasterstwa eklezjalnego jest karmienie ziarnem słowa Bożego tych, którzy podjęli proces dojrzewania, troska o tych, którzy stracili wiarę oraz dostrzeganie i wydobywanie pozytywnych elementów w życiu u osób w sytuacjach nieprawidłowych ${ }^{39}$.

Postulaty papieża Franciszka implikują imperatyw duszpasterskiego zaangażowania Kościoła wobec sytuacji nieregularnych. Kościół powinien

\footnotetext{
35 Tamże, 6.

36 EG 45.

37 Por. AL 211.

38 Por. tamże, 293.

39 Por. tamże, 76, 292.
} 
modlić się o łaskę nawrócenia osób w nich żyjących ${ }^{40}$, zachęcać je do czynienia dobra oraz włączać we wspólnotę wierzących. Papież wychodzi z założenia, że jeśli związek charakteryzuje się stabilnością, głębokim uczuciem, odpowiedzialnością wobec potomstwa i zdolnością przezwyciężania kryzysów, to jest sam w sobie szansą dojścia do pełni, czyli przyjęcia sakramentu małżeństwa (przy braku przeszkód z prawa kanonicznego) ${ }^{41}$. Niewątpliwie zadaniem Kościoła jest towarzyszenie wszystkim tym, którzy nie mogą lub nie chcą obecnie zbliżyć się do wspomnianego ideału. W ten sposób może on dla jednych być wsparciem, a dla drugich inspiracją. Papież przywołuje w tym miejscu biblijny obraz spotkania Pana Jezusa z Samarytanką. Chrystus skierował swoje słowo do jej pragnienia prawdziwej miłości i towarzyszył jej dojrzewaniu do pełni ${ }^{42}$.

Nieprawdziwym byłoby stwierdzenie, że adhortacja apostolska Amoris laetitia zupełnie nie zmienia stanowiska Kościoła dotyczącego duszpasterstwa rozwiedzionych. Papież, co prawda, nie wprowadza nowej doktryny, nie ustanawia nowych norm, ani też nie proponuje nowego narzędzia interpretacyjnego. Zmienia jednak optykę duszpasterską. Franciszek nie zrywa z tradycją Kościoła, ale z dotychczasowym, zawężonym, neoscholastycznym podejściem. Przypomina, że na czyn ludzki trzeba spojrzeć w sposób całościowy, zwierający jego konstytutywne elementy: przedmiot, intencja i okoliczności. W myśl tomistycznej teorii działania pierwszoplanową rolę w ocenie czynu ludzkiego pełni intencja działającego i jego wolitywne ukierunkowanie na cel działania. Ocena czynu musi się więc dokonać w kontekście rozeznania sytuacji życiowej danej osoby wraz z samooceną jej sumienia ${ }^{43}$. Przed przeciwnym rozumieniem przestrzega nas papieskie napomnienie, ażeby nie zdoktrynalizować Ewangelii, „Zamieniając ją w martwe kamienie, by rzucać nimi w innych" 4 .

${ }^{40}$ J. Goleń, The Renewal of Pastoral Care of the Family in the Light of the Apostolic Exhortation Amoris Laetitia, „Roczniki Teologiczne” 64 (2017), z. 6, s. 98.

${ }^{41}$ Por. AL 78.

${ }^{42}$ Por. tamże, 294.

${ }^{43}$ Por. K. Glombik, Franciszek - kontrowersyjne nauczanie czy kontrowersyjna recepcja, w: Mosty, nie mury. 5 lat pontyfikatu Franciszka, M. Lis (red.), Opole 2018, s. 140.

${ }^{44}$ AL 49. 
Franciszek wiele uwagi poświęca analizie współczesnych uwarunkowań zarówno na płaszczenie obiektywnej (antropologiczno-społeczno-gospodarczej ${ }^{45}$ ), jak i subiektywnej (dotyczącej sytuacji nieregularnych ${ }^{46}$ ). W wizji duszpasterstwa Kościoła zaproponowanej przez papieża dominuje Boża logika miłości i miłosierdzia. Proklamuje on Kościół służący zbawieniu wszystkich ludzi, a nie zapatrzony w siebie i skupiający na obronie własnych przywilejów ${ }^{47}$. Patrząc na Kościół, nie widzi owczarni, ale konkretne owce. Człowieka postrzega jako osadzonego w swych obiektywnych oraz subiektywnych uwarunkowaniach nieraz niemożliwych do pokonania. Hermeneutyka osoby pozwala papieżowi na opuszczenie bezpiecznej strefy sztywnych norm moralnych, aby wyruszyć na nieogarnione wody Bożego miłosierdzia.

\section{BIBLIOGRAFIA}

Buttiglione R., Przyjacielska odpowiedź krytykom Amoris Laetitia, Kraków 2018.

Coccopalmerio F., Przewodnik po ósmym rozdziale adhortacji Amoris laetitia papieża Franciszka, Kraków 2017.

Czaja, Papieża Franciszka wizja i odnowa Kościoła, w: Mosty, nie mury. 5 lat pontyfikatu Franciszka, M. Lis (red.), Opole 2018, s. 17-31.

Diocesi di Roma, "La letizia dellamore": il cammino delle famiglie a Roma (19.09.2016), 4. VI.

Franciszek, Adhortacja apostolska Evangelii gaudium o głoszeniu Ewangelii we współczesnym świecie (24.11.2013).

Franciszek, Posynodalna adhortacja apostolska Amoris laetitia o miłości w rodzinie (19.03.2016).

Glombik K., Franciszek - kontrowersyjne nauczanie czy kontrowersyjna recepcja, w: Mosty, nie mury. 5 lat pontyfikatu Franciszka, M. Lis (red.), Opole 2018, s. 131-149.

Glombik K., Wokót interpretacji „Amoris laetitia”. Próba wyttumaczenia niektórych wątpliwości, „Etos” 30 (2017) nr 4 (120), s. 301-317.

Golen J., The Challenges of Accompanying Families in Light of the Apostolic Exhortation Amoris Laetitia, „Rocznik Teologii Katolickiej”, t. XVII/1, 2018, s. 103-117.

Goleń J., Pastoral Accompaniment for People in Irregular Situations, w: Catholic Family

45 Zob. tamże, 31-57.

${ }^{46}$ Zob. tamże, 296-300.

47 Por. A. Czaja, Papieża Franciszka wizja i odnowa Kościoła, w: Mosty, nie mury. 5 lat pontyfikatu Franciszka, M. Lis (red.), Opole 2018, s. 31. 
Ministry. The Scientific Reflection and the Practical Ministry of the Church, red. J. Goleń, R. Kamiński, G. Pyźlak, Lublin 2018, s. 453-463.

Goleń J., The Renewal of Pastoral Care of the Family in the Light of the Apostolic Exhortation Amoris Laetitia, „Roczniki Teologiczne” 64 (2017), z. 6, s. 95-114.

Góralski W., Adhortacja apostolska Amoris laetitia papieża Franciszka. Prezentacja dokumentu z komentarzem do nn. 300-308, Płock 2016.

Jan Paweł II, Adhortacja apostolska Familiaris consortio o zadaniach rodziny chrześcijańskiej w świecie współczesnym (22.11.1981).

Katechizm Kościoła Katolickiego, Poznań 1994.

Kupczak J., Źródła sporu o Amoris laetitia, Poznań 2018.

Mroczkowski I., Etos miłosierdzia a wierność małżeńska. Moralne dylematy osób żyjących w zwiazkach niesakramentalnych, Płock 2017.

Müller G.L., Przedmowa. Dlaczego adhortacja Amoris laetitia może i powinna być rozumia$n a$ w sensie ortodoksyjnym, w: R. Buttiglione, Przyjacielska odpowiedź krytykom Amoris Laetitia, Kraków 2018, s. 5-28.

Schockenhoff E., Zerwanie z tradycją czy niezbędny dalszy rozwój? Dwa sposoby rozumienia posynodalnej adhortacji Amoris laetitia, Zjazd Stowarzyszenia Teologów Moralistów, Nysa (12.06.2017).

Synod Biskupów. XIV Zwyczajne Zgromadzenie Ogólne, Relacja końcowa Synodu Biskupów dla Ojca świętego Franciszka (24.10.2015).

Terlikowski T.P., Franciszek zrywa z Janem Pawłem, https://tygodnik.tvp.pl/35089570/ franciszek-zrywa-z-janem-pawlem [data dostępu: 04.10.2018]. 